\title{
High Temperature Plastic Instability and Dynamic Strain Aging in the Tensile Behavior of AISI 316 Stainless Steel
}

\author{
Sergio Neves Monteiro ${ }^{a *}$, Frederico Muylaert Margem ${ }^{b}$, Verônica Scarpini Candido $^{a}$,
} André Ben-Hur da Silva Figueiredo ${ }^{a}$

\author{
${ }^{a}$ Programa de Ciência dos Materiais, Instituto Militar de Engenharia - IME, Praça General \\ Tibúrcio, 80, Urca, 22290-270, Rio de Janeiro, RJ, Brazil \\ ${ }^{b}$ Laboratório de Materiais Avançados, Universidade Estadual do Norte Fluminense Darcy Ribeiro - \\ UENF, Av. Alberto Lamego, 2000, 28013-602, Campos dos Goytacazes, RJ, Brazil
}

Received: November 16, 2016; Revised: August 09, 2017; Accepted: September 17, 2017

\begin{abstract}
The plastic instability in the stress-strain curve and work hardening of a type AISI 316 austenitic stainless steel was investigated in the high temperature range of $150^{\circ} \mathrm{C}$ to $800^{\circ} \mathrm{C}$ for two strain rates. The results indicate the occurrence of plastic instability and serrations between $200^{\circ} \mathrm{C}$ and $650^{\circ} \mathrm{C}$ with peaks in both the tensile strength and work hardening rate. These plastic instability/serrations are associated with dynamic strain aging behavior. As a consequence, within the temperature interval of plastic instability, a negative value for the strain rate sensitivity was found. Based on the activation energy, it is proposed that a mechanism of substitutional solute atoms interaction with dislocations be responsible for the plastic instability.
\end{abstract}

Keywords: AISI 316 stainless steel, plastic instability, tensile behavior

\section{Introduction}

Several processes in industrial engineering sectors, such as petrochemical refinery and nuclear reactor are ever more demanding high temperature resistant materials. Stainless steels are among these typical materials that combine heat and corrosion resistances in association with cost and commercial advantages. Today, stainless steels are increasingly being considered to severe high temperature conditions in critical components of nuclear reactors like the pressure vessel, which has to stand an aggressive internal environment for long periods of time. The mechanical properties of stainless steels at high temperatures have been the subject of earlier investigations ${ }^{1-4}$. In particular, the main mechanical properties of type AISI 316 austenitic stainless steels were studied by Conway et $\mathrm{al}^{2}$. In that work, the relationship between the tensile stress and the strain was analyzed in terms of double logarithm graphs. In another earlier publication, Wray and Richmond $^{3}$, based on fundamental aspects, discussed the interaction between the state variables: stress, strain and strain rate applied to experimental results. One important characteristic observed by both research group ${ }^{2,3}$, regarding the temperature dependence of the AISI 316 steel tensile strength, was the occurrence of maximum values in the range of 200 to $600^{\circ} \mathrm{C}$. This was interpreted as a consequence of aging processes. In this range, it was also found instabilities in the stress-strain curves in the form of serrations. Michel et $\mathrm{al}^{4}$ investigated the dislocation substructure in an AISI 316

*e-mail: snevesmonteiro@gmail.com steel and concluded that dislocation arrangements could be correlated with work hardening stages. The authors attributed the increase in strength to dynamic strain aging (DSA).

Recent works ${ }^{5-11}$ corroborate the existence of work hardening stages in AISI 316 steel from room temperature up to $750^{\circ} \mathrm{C}$. In particular, Choudhary and Christopher ${ }^{5,7}$ as well as Christopher and Choudhary ${ }^{6,8}$ disclosed the existence of three work hardening stages in each tensile curve. Stage II was found to suffer a noticeable influence of DSA in terms of an increase in $\mathrm{d} \sigma / \mathrm{d} \varepsilon$ vs. $\sigma$ in the interval from $200^{\circ} \mathrm{C}$ to $650^{\circ} \mathrm{C}$. At higher temperatures, dominance of dynamic recovery was observed in association with a larger stage III, which suggests concurrent processes of annihilation of dislocations over storage of dislocations during DSA. Gupta et al. ${ }^{9}$ used artificial neural network to predict the flow stress of AISI 316 steel in association with DSA. They concluded that well-trained artificial neural network models provide fast, accurate and consistent results, especially in the DSA regime of AISI 316 steel. Byun et $\mathrm{al}^{10}$ reported dislocation cells dominant microstructures at elevated temperatures and plastic instability in AISI 316 and AISI 316L steels. Armas et al. ${ }^{11}$ associated instabilities in the mechanical cycling behavior and dislocation cell arrangements of AISI $316 \mathrm{H}$ and AISI 316 L steels with DSA.

It is also worth mentioning the work of Reddy et al ${ }^{12}$ on creep-fatigue behavior of AISI $316 \mathrm{LN}$ steel at $600^{\circ} \mathrm{C}$. They found that deformation in a relatively short hold period is controlled by dislocation-precipitate interaction 
and DSA. Concurrent occurrence of DSA and thermal recovery determine the cyclic stress response at longer hold periods. Another relevant work on the possible simultaneous occurrence of martensitic transformation and DSA at $15^{\circ} \mathrm{C}$ under strain rate of $10^{-4}$ or $10^{-2} \mathrm{~s}^{-1}$ was presented by Ogawa et al. ${ }^{13}$. The investigated austenitic stainless steels were nonstandard $19 \mathrm{Cr}-8 \mathrm{Ni}$ with 0.05 and $0.14 \mathrm{C}$. Although different than AISI 316, the authors indicate that relatively similar stainless steels with higher carbon content $(0.14 \mathrm{wt} \%)$ would display martensitic transformation assisting DSA at ambient temperature due to local change in the diffusivity of carbon.

In spite of decades of investigations on the work hardening behavior of AISI 316 steel at elevated temperatures, a systematic study on the DSA effects and associated mechanisms have not yet been performed. Therefore, the objective of the present work was to report on the plastic instability, which occurred between 200 and $650^{\circ} \mathrm{C}$ and related DSA effects. Tensile tests were carried out in the temperature interval from 150 to $800^{\circ} \mathrm{C}$ at two different strain rates. Measurements of activation energies allowed a possible DSA mechanism to be proposed.

\section{Experimental Procedure}

The type AISI 316 stainless steel was supplied by the Villares firm, Brazil, in the form of rolled bar, with $10 \mathrm{~mm}$ in diameter. The chemical composition of the investigated steel is presented in Table 1, together with standard specification for AISI 316 steels. In this table, one sees that the investigated AISI 316 steel has a composition within the AISI standard.

The as-received bar was solution treated at $1100^{\circ} \mathrm{C}$ for one hour under vacuum. Cooling also occurred under vacuum by switching off the furnace. Cylindrical specimens were machined from the bar with dimensions, as per the ASTM norm, of $4 \mathrm{~mm}$ in diameter and $24 \mathrm{~mm}$ in length for the reduced section. Before running tensile tests, the specimens were electropolished for a mirror-like surface. Tensile tests were carried out in a model 1125 Instron machine at initial strain rates of $3.5 \times 10^{-3}$ and $3.5 \times 10^{-4} \mathrm{~s}^{-1}$. These strain rates, applied at the beginning of the tensile test by constant crosshead speed of 5 and $0.5 \mathrm{~mm} / \mathrm{min}$, respectively, were maintained until the end of the test. The temperatures during tests were controlled within $1^{\circ} \mathrm{C}$ in the interval from $150^{\circ} \mathrm{C}$ to $800^{\circ} \mathrm{C}$. A vacuum under $10^{-2}$ Torr was produced inside the specimen chamber of the Instron furnace. Transmission electron microscopy (TEM) analysis of tensile fractured specimens at different temperatures and strain rates was conducted in a Jeol microscope operating at $100 \mathrm{kV}$.

\section{Results and Discussion}

Figure 1 shows typical stress-strain curves for the different temperatures at each strain rate. In this figure, instabilities in the flow curve are observed above $200^{\circ} \mathrm{C}$, Figure 1 (a), for the strain rate of $3.5 \times 10^{-4} \mathrm{~s}^{-1}$ and Figure $1(\mathrm{~b})$ for $3.5 \mathrm{x}$ $10^{-3} \mathrm{~s}^{-1}$. These instabilities, particularly the more uniform serrations, are associated with DSA ${ }^{6-9,13}$. Other manifestations are revealed in terms of the temperature dependence of related tensile properties.

Figure 2 shows the effects of strain rate and temperature on the yield stress $(0.2 \%$ offset $)$, Figure $2(a)$, and the ultimate stress, Figure 2(b), of the investigated 316 steel. In Figure 2(a) one should note the continuous decrease of the yield stress with increasing temperature. Small humps are detected around 300,450 and $650^{\circ} \mathrm{C}$ and can be assigned to slight effects of DSA. In Figure 2(b), for the ultimate stress, a significant increase occurred in the base line from 200 to $600^{\circ} \mathrm{C}$. This increase in the ultimate stress has been attributed to DSA in 316 steels $^{4-9}$. However, details of the DSA peaks were not discussed so far. An important point regarding the DSA effects is the inversion in the relative level of the ultimate stress, which becomes higher for lower strain rates. Thus, a negative strain rate sensitivity, $\mathbf{m}$, occurred as earlier observed in stainless steels ${ }^{14,15}$. The value of $\mathbf{m}$ is obtained as ${ }^{16}$ :

$$
m=\left.\frac{\partial \ln \sigma_{m}}{\partial \ln \dot{\varepsilon}}\right|_{\varepsilon, T}
$$

where $\sigma_{\mathrm{m}}$ is the ultimate tensile stress, $\dot{\varepsilon}$ the deformation and $\mathrm{T}$ the temperature.

An average negative, value of the strain rate sensitivity in Figure 2(b) was found to be around $\mathbf{m}=-0.02$, which is consistent with those reported in the literature ${ }^{14,15,17}$ for stainless steels and ultrafine grained titanium in the DSA interval of temperatures. Another point worth noticing in Figure 2(b) is the clear existence of two well defined peaks in the ultimate stress around $300^{\circ} \mathrm{C}$ and $420^{\circ} \mathrm{C}$ for the $3.5 \times 10^{-4} \mathrm{~s}^{-1}$ strain rate curve. A noticeable peak at $450^{\circ} \mathrm{C}$ and a faint peak around $600^{\circ} \mathrm{C}$ may also be observed for

Table 1. Chemical composition (wt\%) of the investigated and standard specification for the type AISI 316 stainless steel.

\begin{tabular}{|c|c|c|c|c|c|c|c|c|c|}
\hline $\begin{array}{l}\text { Type AISI } 316 \\
\text { Stainless Steel }\end{array}$ & $\mathrm{C}$ & $\mathrm{Cr}$ & $\mathrm{Ni}$ & Mo & $\mathrm{Mn}$ & $\mathrm{Si}$ & $\mathrm{P}$ & $\mathrm{S}$ & $\mathrm{N}$ \\
\hline Investigated & 0.05 & 18.0 & 12.8 & 2.64 & 1.58 & 0.51 & 0.0022 & 0.013 & 0.32 \\
\hline Specified Standard & $0.08 \max$ & 16 to 18 & 10 to 14 & 2 to 3 & $2 \max$ & $1 \max$ & $\begin{array}{c}0.045 \\
\max \end{array}$ & $0.03 \max$ & $\mathrm{N} / \mathrm{A}^{*}$ \\
\hline
\end{tabular}

*N/A: Not specified by standards 

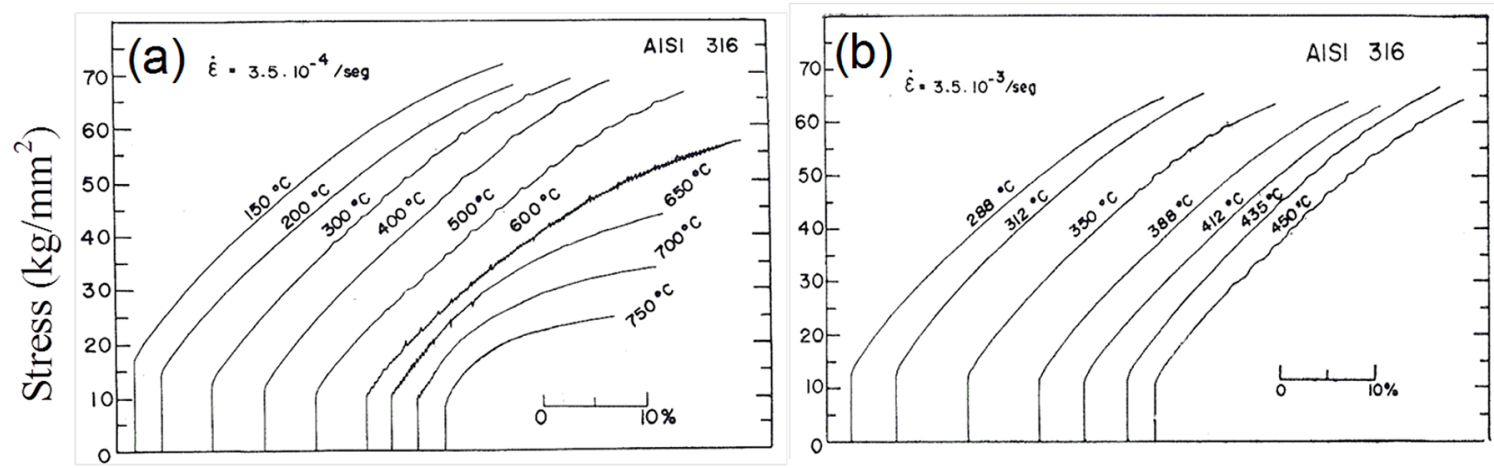

\section{Strain $\varepsilon(\%)$}

Figure 1. Typical stress-strain curves for type AISI 316 stainless steel tested at different temperatures and two strain rates: (a) $3.5 \times 10^{-4}$ and (b) $3.5 \times 10^{-3} \mathrm{~s}^{-1}$.

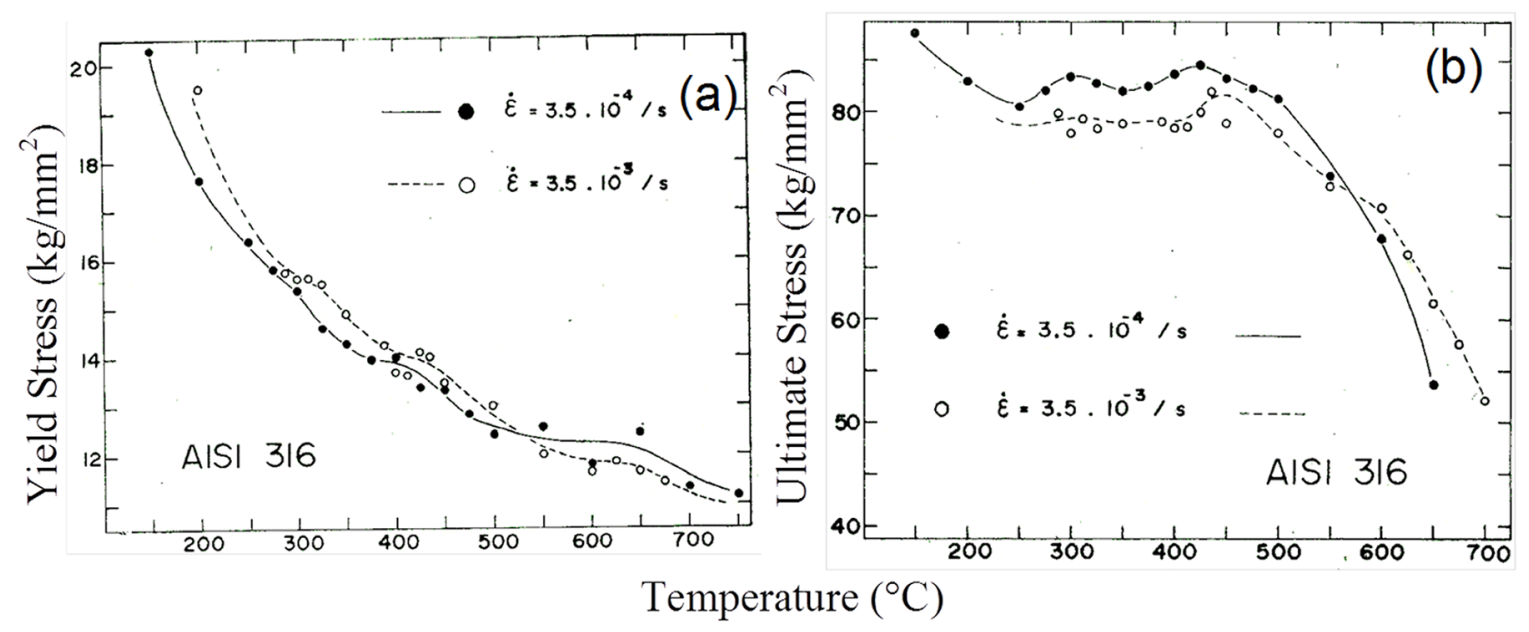

Figure 2. Variation of (a) yield stress and (b) ultimate stress of type AISI 316 stainless steel with temperature for two strain rates.

the $3.5 \times 10^{-4} \mathrm{~s}^{-1}$ strain rate. The peak around $420^{\circ} \mathrm{C}, 3.5 \mathrm{x}$ $10^{-4} \mathrm{~s}^{-1}$, is apparently shifted to $450^{\circ} \mathrm{C}$ for the $3.5 \times 10^{-3} \mathrm{~s}^{-1}$ strain rate curve. This allowed a rough calculation of the activation energy, $\mathrm{Q}$, by the equation ${ }^{17}$ :

$$
\dot{\varepsilon}=A \exp \left(-\frac{Q}{R T}\right)
$$

The value of the activation energy was found to be $Q$ $\sim 319 \mathrm{~kJ} / \mathrm{mol}$. This activation energy is much higher than those reported for carbon and nitrogen diffusing in austenitic steels, Q 134/148 kJ/mol ${ }^{18}$. However, it is close to those for chromium (Cr), Q $334 \mathrm{~kJ} / \mathrm{mol}$ and nickel $(\mathrm{Ni}), \mathrm{Q} \sim$ $282 \mathrm{~kJ} / \mathrm{mol}$, in austenitic steels ${ }^{19}$.

Figure 3 shows the temperature dependence of both the uniform strain, at the ultimate stress, and the total strain at rupture. In spite of the great dispersion, this figure reveals a tendency to a minimum at $250^{\circ} \mathrm{C}$ and a maximum at about $600^{\circ} \mathrm{C}$. This minimum in ductility is known as the blue brittle effect and associated with $\mathrm{DSA}^{20}$. Still another evidence of DSA is a peak in the average work hardening rate.
Figure 4 presents the variation of the average work hardening rate (WHR) defined by Garde et al. ${ }^{20}$ as the difference of tensile stresses $(\Delta \sigma)$ in the interval of plastic strain from 0.5 to $5.0 \%$, as a function of the temperature:

$$
W H R=\frac{\sigma_{5 \%}-\sigma_{0.5}}{\varepsilon_{5 \%}-\varepsilon_{0.5}}=\frac{\Delta \sigma}{\Delta \varepsilon}
$$

In this figure, three well defined peaks in the WHR are observed around 300,430 and $650^{\circ} \mathrm{C}$. The first two peaks clearly show a tendency to shift from the lower towards the higher strain rate. This would also allow one to evaluate the activation energy using Eq. (2). The average activation energy for the first peak around $300^{\circ} \mathrm{C}$ was found as $\sim 314 \mathrm{~kJ} / \mathrm{mol}$, while that for the second peak around $430^{\circ} \mathrm{C}$ was $\sim 319 \mathrm{~kJ} /$ mol. As in the case of peaks in the ultimate stress, shown in Figure 2(a), the activation energies for these peaks in the WHR can be imputed to the interaction of $\mathrm{Cr}$ and/or $\mathrm{Ni}$ with dislocation, as suggested by the high activation energy $\sim 334$ or $282 \mathrm{~kJ} / \mathrm{mol}$, respectively, reported by Peng et al. ${ }^{19}$. 


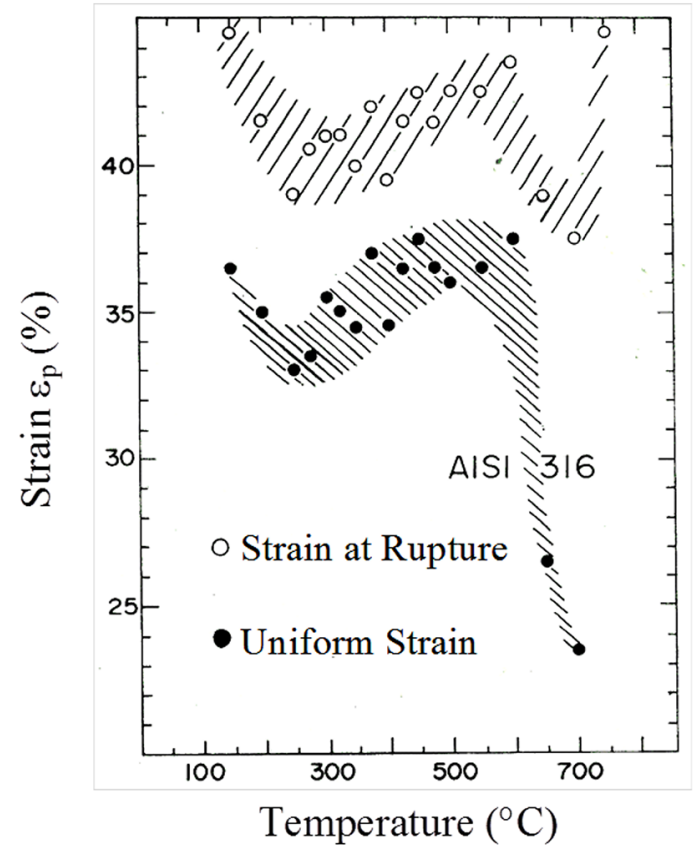

Figure 3. Temperature dependence of uniform strain and total strain for AISI 316 stainless steel.

The dislocation structure contributes to support the mechanism of solute atom interaction with dislocations. Figure 5 shows TEM typical images of dislocation arrangements at the end fracture of tensile tests. The sample fractured at $400^{\circ} \mathrm{C} /$ $\dot{\varepsilon}=3.5 \times 10^{-4} \mathrm{~s}^{-1}$, Figure 5(a), reveals the classic cell structure with wooly tangle of dislocations at cell walls, typical of $\mathrm{DSA}^{4,10}$. It is suggested that $\mathrm{Cr}$ and $\mathrm{Ni}$ atoms interaction with dislocation are the main responsible for the arrangement in Figure 4(a). No precipitates were observed that could justify the existence of chromium carbide. The sample fractured at $700^{\circ} \mathrm{C} / \dot{\varepsilon}=3.5 \times 10^{-4} \mathrm{~s}^{-1}$, Figure $5(\mathrm{~b})$, shows clear evidence of subgrains, which occurs by dislocation annihilation,

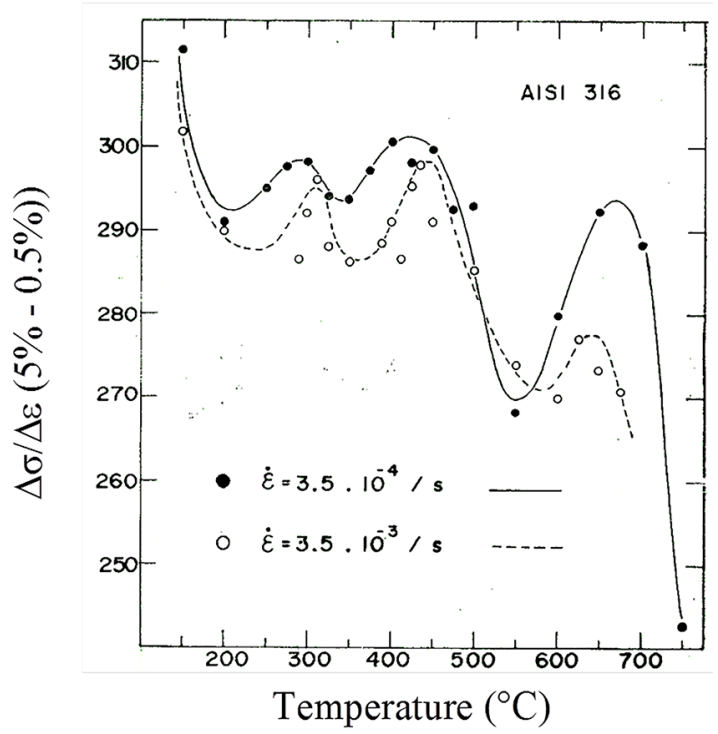

Figure 4. Variation of the average work hardening rate of type AISI 315 stainless steel with temperature for two strain rates.

characteristic of dynamic recovery ${ }^{5-8}$. At this condition, DSA is no longer occurring and dislocation move free from their solute atom atmosphere to form low energy sub-boundaries.

\section{Final Remarks}

The results in Figure 1 to 5 confirm the existence of dynamic strain aging (DSA) effects in type AISI 316 austenitic stainless steel. These effects are associated with: (I) serrations in stress-strain curves, Figure 1; (II) small humps in the temperature dependence of the yield stress, Figure 2(a); (III) peaks in the variation of the ultimate stress with temperature, Figure 2(b); (IV) minimum in both uniform and total strain, Figure 3, (V) peaks in the work hardening rate (WHR), Figure 4, and the tangled dislocation cells, Figure 5. From
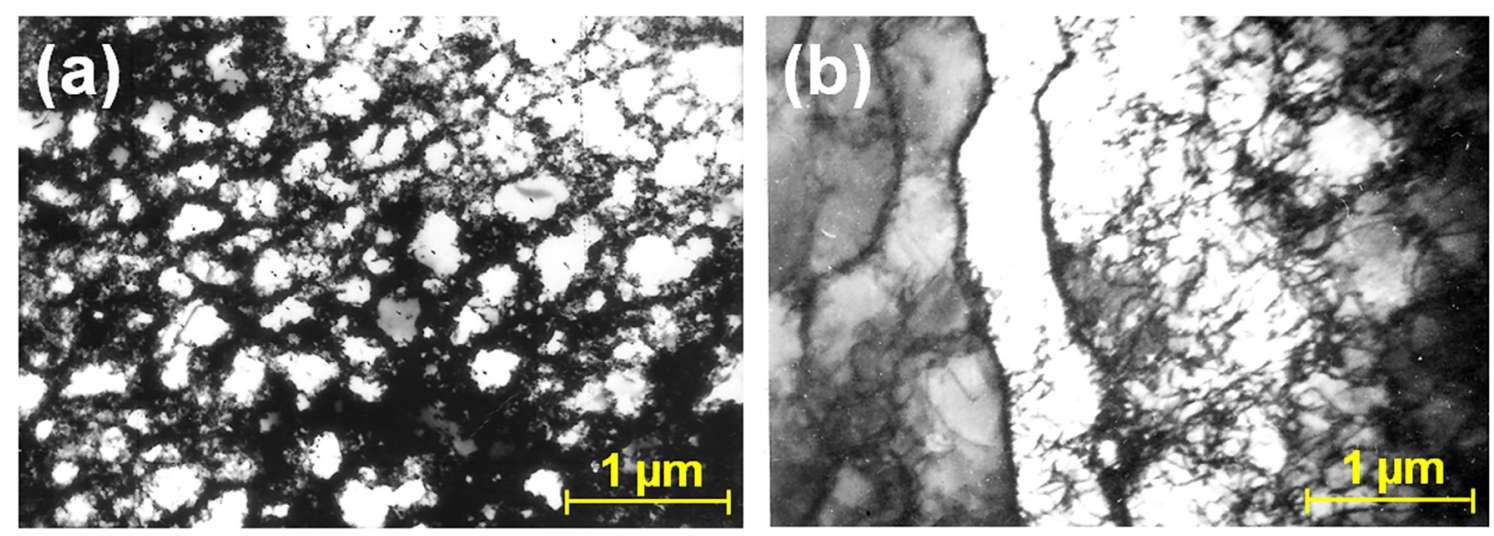

Figure 5. Dislocation structure in fractured specimens of AISI 316 steel: (a) $400^{\circ} \mathrm{C}$ and $\varepsilon^{\circ}=3.5 \times 10^{-4} \mathrm{~s}^{-1}$; (b) $700^{\circ} \mathrm{C}$ and $\varepsilon^{\circ}=3.5 \times 10^{-4} \mathrm{~s}^{-1}$. 
these results, it is possible to indicate that, for the interval of strain rates from $3.5 \times 10^{-4}$ to $3.5 \times 10^{-3} \mathrm{~s}^{-1}$, the AISI 316 steel undergoes DSA in the temperature range of $200^{\circ} \mathrm{C}$ to $650^{\circ} \mathrm{C}$. As a consequence of DSA, a negative strain rate sensitivity, $\mathrm{m}=-0.02$, which was for the first time detected between $300^{\circ} \mathrm{C}$ to $500^{\circ} \mathrm{C}$. Moreover, an average activation energy, measured by the peaks in both the ultimate stress, Figure 2(a), and WHR, Figure 4, was found as Q $317 \mathrm{~kJ} /$ mol. As aforementioned, this value of $\mathrm{Q}$ is much greater than the activation energy for interstitial atoms such as $C$, $\mathrm{N}, \mathrm{O}$ and $\mathrm{H}$. According to Peng et $\mathrm{al}^{19}$, it is probable that diffusion of $\mathrm{Cr}$ with $\mathrm{Q} \sim 334 \mathrm{~kJ} / \mathrm{mol}$ be the responsible for DSA in 316 steel. Another substitutional atom, Ni with Q $\sim 282 \mathrm{~kJ} / \mathrm{mol}$ might also contribute to the high temperature DSA effects in 316 steel.

Finally, the minimum in ductility shown in Figure 3 can be explained by means of the combination of extreme values in the ultimate stress and work hardening rate. Indeed, the Considère Criterion ${ }^{16}$,

$$
\frac{\Delta \sigma}{\Delta \varepsilon}=\sigma
$$

which calculates the onset of necking, can be used to explain minimum and maximum in ductility shown in Figure 3. Combination of high or low values of WHR and ultimate stress may result in smaller or larger values of necking strain $^{20}$.

\section{Conclusions}

- $\quad$ Type AISI 316 steel presents anomalous behavior in the mechanical properties evaluated by tensile tests in the range of temperatures from $200^{\circ} \mathrm{C}$ to $650^{\circ} \mathrm{C}$ and at stain rates of $3.5 \times 10^{-3}$ and $3.5 \times 10^{-4} \mathrm{~s}^{-1}$.

- Instabilities in the stress-strain curves, particularly the more uniform serrations were associated with dynamic strain aging (DSA) effects.

- Peaks in the variation of both the ultimate stress and the work hardening rate with temperature as well as tangled dislocation cell structures were found and attributed to DSA manifestations. These effects caused a negative strain rate sensitivity, for the first time evaluated as $\mathrm{m}=-0.02$.

- Evaluation of activation energies, both from tensile strength and work hardening rate peaks, gave an average value of $Q=317 \mathrm{~kJ} / \mathrm{mol}$, which is comparable to other previous results and suggests the diffusion of chromium and/or nickel interacting with dislocations as the DSA mechanism in AISI 316 steel.

\section{Acknowledgements}

The authors thank the support to this investigation by the Brazilian agencies: CNPq, CAPES and FAPERJ.

\section{References}

1. Simmons WF, Van Echo JA. Report on the elevated temperature properties of stainless steels, ASTM Data Series, Publication DS 5-51 (formely STP 124). West Conshohocken: ASTM International; 1965.

2. Conway JB, Berling JT, Stentz RH, Salyards DG. Stress strain behavior of several stainless steels to elevated temperature. General Electric Technical Report. GEMP 686, Fairfield; 1969.

3. Wray PJ, Richmond O. Experimental approach to a theory of plasticity at elevated temperatures. Journal of Applied Physics. 1968;39(12):5754-5761.

4. Michel DJ, Moteff J, Lovell AJ. Substructure of type 316 stainless steel deformed in slow tension at temperatures between $21^{\circ}$ and $816^{\circ}$ C. Acta Metallurgica. 1973;21(9):1269-1277.

5. Choudhary BK, Christopher J. Stage-II tensile work hardening behavior of type $316 \mathrm{~L}(\mathrm{~N})$ austenitic stainless steel. Materials Science and Engineering: A. 2016;651:486-489.

6. Christopher J, Choudhary BK. On the assessment of tensile work hardening behaviour of type $316 \mathrm{~L}(\mathrm{~N})$ austenitic stainless steel in the framework of $\theta \sigma \mathrm{d}$ vs. $\sigma \mathrm{d}$ using flow stress contribution from dislocations. International Journal of Pressure Vessels and Piping. 2016;146:151-160.

7. Choudhary BK, Christopher J. Tensile flow and work hardening behaviour of type $316 \mathrm{~L}(\mathrm{~N})$ austenitic stainless steel in the framework of one-internal-variableand two-internal-variable approaches. Materials Science and Engineering: A . 2015;636:269278.

8. Christopher J, Choudhary BK. Kinetics of uniaxial tensile flow and work hardening behavior of type $316 \mathrm{~L}(\mathrm{~N})$ austenitic stainless steel in the framework of two-internal-variable aproach. Metallurgical and Materials Transactions A. 2015;46(2):674-687.

9. Gupta AK, Singh SK, Swathi R, Hariharan G. Prediction of flow stress in dynamic strain aging regime of austenitic stainless steel 316 using artificial neural network. Materials \& Design . 2012;35:589-595.

10. Byun TS, Hashimoto N, Farrel K. Temperature dependence of strain hardening and plastic instability behaviors in austenitic stainless steels. Acta Materialia. 2004;52(13):3889-3899.

11. Armas AF, Bettin OR, Alvarez-Armas I, Rubiolo GH. Strain aging effects on the cyclic behavior of austenitic stainless steels. Journal of Nuclear Materials. 1998;155-157(Pt 2):644-649.

12. Reddy GVP, Sandhya R, Sankaran S, Parameswaran P, Laha $\mathrm{K}$. Creep-fatigue interaction behavior of $316 \mathrm{LN}$ austenitic stainless steel with varying nitrogen content. Materials \& Design. 2015;88:972-982. 
13. Ogawa T, Koyama M, Tasan CC, Tsuzaki K, Noguchi H. Effects of martensitic transformability and dynamic strain age hardenability on plasticity in metastable austenitic steels containing carbon. Journal of Materials Science. 2017;52(13):7868-1882.

14. Naybour RD. Hardening during deformation of an $18 \mathrm{Cr} / 12 \mathrm{Ni} / \mathrm{Nb}$ austenitic steel at $650^{\circ}$ C. Acta Metallurgica. 1965;13(11):11971207.

15. Bressanelli JP, Moskowitz A. Effects of strain rate, temperature and composition on tensile properties of metastable austenitic steels. Transactions of ASM. 1966;59:223-239.

16. Meyers MA, Chawla KK. Mechanical Behavior of Materials. 2nd ed. New York: Cambridge University Press; 2009.
17. Lopes FPD, Lu CH, Zhao S, Monteiro SN, Meyers MA. Room Temperature Dynamic Strain Aging in Ultrafine-Grained Titanium. Metallurgical and Materials Transactions A. 2015;46(10):44664477.

18. Callister WD Jr, Rethwisch DG. Materials Science and Engineering: An Introduction. 8th ed. Hoboken: John Wiley \& Sons; 2010.

19. Peng K, Qian K, Chen W. Effect of dynamic strain aging on high temperature properties of austenitic stainless steel. Materials Science and Engineering: A. 2004;379:(1-2):372-377.

20. Garde AM, Santhanam AT, Reed-Hill RE. The significance of dynamic strain aging in titanium. Acta Metallurgica. 1972;20(2):215-220. 